\title{
Integrating Service Learning and Civic Engagement Opportunities into Professionally Accredited Business and IS Programs in the US and Europe to Enhance Student Learning Outcomes, Research, and Local Community/Economic Development
}

\author{
Gary J. DeLorenzo, California \\ University of Pennsylvania, \\ California, PA, USA
}

delorenzo@calu.edu

\author{
Frederick G. Kohun \\ Robert Morris University, \\ Moon Township, PA, USA \\ kohun@rmu.edu
}

Daryl Nord and Jeretta Horn Nord
Oklahoma State University, Stillwater, OK, USA

daryl.nord@okstate.edu; jeretta.nord@okstate.edu

\begin{abstract}
This paper extends previous research on service learning to the context of compatibility with professionally accredited business oriented information systems programs in the US and Europe. Service learning has historically integrated community service with the application of academic instruction. Recent research has highlighted the compatibility and integration of service learning into professionally accredited IS programs and curriculum. With the recent academic focus on community volunteerism and civic responsibility, this paper discusses the bridge of IS concept and practice into the service learning domain. A case study of the integration of the systems development life cycle into database design, development, and implementation into a student led community based projects is presented as a model that bridges theory and practice into the community. This research extends the discussion to include accredited programs beyond AACSB, ABET to include European accreditations such as FIBAA.
\end{abstract}

Keywords: Service learning, civic engagement, computer information systems, AACSB, ABET, FIBAA

Material published as part of this publication, either on-line or in print, is copyrighted by the Informing Science Institute. Permission to make digital or paper copy of part or all of these works for personal or classroom use is granted without fee provided that the copies are not made or distributed for profit or commercial advantage AND that copies 1) bear this notice in full and 2) give the full citation on the first page. It is permissible to abstract these works so long as credit is given. To copy in all other cases or to republish or to post on a server or to redistribute to lists requires specific permission and payment of a fee. Contact Publisher@InformingScience.org to request redistribution permission.

\section{Introduction}

This paper extends previous research on service learning to the context of compatibility with professionally accredited business oriented information systems programs in the US and Europe. Service learning is discussed as a pedagogical teaching method, how it differs from traditional classroom teaching, its criti- 
Integrating Service Learning and Civic Engagement Opportunities

cisms, and strategies for implementation. Additionally, the current trend for academic program accreditation with a focus on rigorous standardized metrics aimed at validating and certifying academic programs for quality is introduced with respect to service learning compatibility. Finally an accreditation compatible IS service learning project is presented.

\section{Service Learning}

Service learning is both a method of teaching and a way of learning that integrates community service with instruction designed to promote civic responsibly (Battistoni, 2002). Within this learning environment, educators facilitate students' engagement in problem-solving activities comprised of sensory awareness, emotions, physical conditions, and cognition (Carver, 1997). This theory builds on Dewey's (1916) concept of situational learning where learning is the result of interactions between the individual and the environment. The service experience provides both a process of acquiring new knowledge through reflection, and an opportunity for further inquiry within the context of a given situation (Giles \& Eyler, 1994).

Stanton, Giles, and Cruz (1999) indicated that service learning is an effective model for creating and studying a highly authentic learning environment, where instruction emphasizes the idea that much of what is learned is specific to the situations in which it is learned (Sweeney \& Paradis, 2004). These experiences include activities that are participatory, interactive, and representative of real-world events (Wenger, McDermott, \& Snyder, 2002). From an instructional perspective, learning is anchored in real contexts, where problem solving, critical thinking, and reflection are required (Howard, 1998).

Social interactions, which play a fundamental role in service learning activities, allow students to engage in debate, ask questions, state opinions, negotiate meanings, and resolve conflicts. All of these behaviors are believed to lead to reflection and internalization of new understandings (Brown, Metz, \& Campione, 1996). In many ways, this is similar to Vygotsky's (1978) theory of social learning, which assumes that cognitive development occurs twice: first, between people (interpsychological) and then inside the individual (intrapsychological). A second aspect of Vygotsky's theory is the idea that the potential for cognitive development depends upon the "zone of proximal development" (ZPD): a level of development attained when people engage in social behavior. This theory assumes that skills developed with guidance or peer collaboration exceed what can be attained alone.

Peer feedback in service learning activities occurs when students observe each other testing, challenging, and revising ways of thinking about a particular problem. This iterative method of learning is critical to the formation of a collective knowledge base from which students are able to gain deeper understandings of the thinking processes of the community. Social learning theory emphasizes the importance of observing and modeling the behaviors, attitudes, and emotional reactions of others (Brown \& Palincsar, 1989; Jonassen \& Henning, 1999). Bandura (1977) stated:

Learning would be exceedingly laborious, not to mention hazardous, if people had to rely solely on the effects of their own actions to inform them of what to do. Fortunately, most human behavior is learned observationally through modeling: from observing others one forms an idea of how new behaviors are performed, and on later occasions this coded information serves as a guide for action. (p. 22)

\section{How Service Learning Differs From Traditional Classroom Experiences}

According to Weigert (1998), six elements differentiate and characterize service learning from traditional classroom experiences. Three of these elements focus on instruction: (1) the service 
flows from and into course objectives; (2) assignments requiring reflection integrate the service with course objectives; and (3) the assignment is assessed and evaluated. The other three elements focus on the community: (1) the service is meaningful to the community; (2) the service meets a need or goal; and (3) the community defines the need or goal.

McPherson (1996) identified the critical components for developing service learning activities that address all six of these elements:

- Service-learning activities maximize student participation in selecting, designing, implementing, and evaluating the service project.

- Service-learning activities value diversity in participants, practice, and outcomes.

- Service-learning activities promote communication and interaction with the community and encourage partnerships and collaboration.

- Students prepare for all aspects of their service work, including a clear understanding of the task, the skills and information required to complete the task, awareness of safety precautions, and knowledge about and sensitivity to colleagues.

- Student reflection takes place before, during, and after service; uses multiple methods to encourage critical thinking; and is central in the design and fulfillment of curricular objectives.

- Multiple methods are designed to acknowledge, celebrate, and validate student service work.

Essential for quality service learning instruction is the development of clear educational goals that require students to construct their own knowledge and understandings about a given problem. Lesh (2002) explained that to learn about the nature of students' developing knowledge, it is useful to focus on tasks in which the resulting products demonstrate significant information about the ways of thinking that produced them. This means that students need to be able to communicate how they interpreted a task or problem-solving situation. Within a service learning project, students plan problem-solving strategies, challenge ideas, monitor progress, test various solutions, and explain outcomes to each other. As students make sense of their experiences through testing, reflecting, modifying, and refining their thinking, knowledge is constructed.

\section{Criticisms of Service Learning}

Currently service learning is gaining popularity in higher education, but there are some who do not agree with the practice (Mattson, 1998). These critics contend that the service component waters down the curriculum, further weakening the quality of higher education, and that the time students spend volunteering in community agencies as part of a course might be better spent in the library or laboratory (Gray, Ondaatje, \& Zakaras, 1999). To address this concern, Battistoni (2002) emphasizes the importance of selecting placements intentionally to meet the learning objectives of the course. The organization benefiting from the service should be considered a partner in education providing structured opportunities for students to critically reflect on the civic nature of their experience.

Manchester and Baiocchi (2001) question if service learning can do more harm than good when the motive to serve may supersede the needs as defined by the community being served. In other words, what is more important - the instruction or the service? Is it really possible to meet both the intended learning objectives and the community's needs? Howard (1998) argues that it is essential to create opportunities that are relevant and meaningful to both the community and the students. The purposeful planning, design, and implementation of activities around specific 
Integrating Service Learning and Civic Engagement Opportunities

learning objectives should be done in collaboration with the community benefiting from the service to avoid conflicts between instructional and service objectives.

\section{Benefits of Service Learning; Strategies for Implementation}

Research indicates that well-implemented service learning programs support the long-term development of civic responsibility, while the impact of the activities address immediate intellectual and social benefits for students and the communities they serve (Billig \& Furco, 2002; MendelReyes, 1998). Roehlkepartain (2007), however, cautioned that positive outcomes are not automatic and will vary depending on the focus, scope and quality of the learning experience. $\mathrm{He}$ identified specific benefits for each stakeholder (students, campus, and community) to use as a benchmark for success, including:

- Service-learning gives an intentional strategy for addressing goals for learning and personal development through civic engagement and community service.

- Service-learning cultivates connections between the organization, schools, higher education, and other community groups.

- Service-learning increases program staff and volunteers' level of engagement, leadership capacity, and satisfaction with their work.

- Service-learning reinforces effective development practices, providing appropriate structure, supportive relationships, opportunities to belong, positive social norms, opportunities for skill building; and integration of school and community efforts.

In order to build an effective program that can attain benefits for each stakeholder, there must be: (1) teacher commitment; (2) a mutually beneficial partnership between the school and the community agency; (3) institutional commitment. The collaborative relationships fostered in this learning environment should be maintained through formal agreements and memorandums of understanding that clearly articulate the roles and responsibilities for each partner. Abregana (2006) suggested four different models for addressing these roles and implementing a service learning curriculum: (1) as part of a course, (2) as a specially designed course, (3) as a departmental program, or (4) as a departmental program in collaboration with partner agencies.

\section{Service Learning and Accreditation}

Service learning provides pedagogy options where students gain practical field experience outside the classroom. Generally, service learning is an area reviewed by agencies for those programs seeking accreditation. Accreditation agencies are entities that audit and assess the quality of programs, validate and certify through processes such as reviews on an assessment, self-study, onsite visit, and the accreditation commission's recommendations for improvement, which results in an acceptance or denial for accreditation. In the U.S., the Association to Advance Collegiate Schools of Business (AACSB) evaluates business related programs and ABET Inc.'s Computer Accreditation Commission (ABET-CAC), evaluates computer based programs. Separately, the Foundation for International Business Administration Accreditation (FIBAA) is a Swiss-based accreditation agency found in Europe. AACSB and ABET accreditations are widely accepted in the U.S. and also gained international acceptance in Germany, Spain and Turkey (ABET, 2010). While FIBAA is a similar accreditation agency in Europe, its acceptance as a leading accreditation agency is limited and is found within a few countries, such as Germany, Austria, and Slovenia (FIBAA, 2010).

Service Learning has been successfully integrated into numerous courses required by AACSB. Students can actively apply the business common body of knowledge and associated skill sets to community based projects such as marketing and public relations operations for a local non-profit 
organization that otherwise could not afford such services. FIBAA requires an integrated international dimension, integration of local economic and social considerations, and demonstrable research by the institution, faculty and students both validating and promoting this focus. Service learning through integrated classroom /local community projects, international focused service learning internships or projects, and data collection and research as to the impact and effectiveness of service learning projects on the community can seamlessly satisfy FIBAA requirements.

\section{Service Learning Project - A Case Study}

\section{Motivation and Significance}

This project provided substantial benefits for the students and the Internship Center at XYZ University (XYZ U). As noted above, it used Abregana's model to implement a service learning curriculum "as part of a course" objective. For this case study, the students' service learning opportunities were gained, outside the classroom, by interviewing users to gain an understanding of the Internship Center function, which is responsible for the placement of all student internships at the university. The overall goal was to gain an understanding of their reporting problems, which were generated with incorrect data. In addition to improving reporting, another goal was to design, develop and implement a decision support system to track and monitor the growth and internship trends at XYZ U. Oftentimes in academic settings, students in technical programs do not get the chance to enhance their soft skills (e.g., communication, interviewing, and understanding group dynamics). This service learning project helped students to strengthen their soft skills (e.g. critical thinking, analytical, problem solving) with hard skills (e.g. programming and database development) while getting practical experience in applying the systems development lifecycle to practical information management problems (Schwalbe 2007).

At XYZ U, the Entrepreneur Center was solicited as a support resource for the students, the faculty and the staff for this project. The Entrepreneur Center is an organizational resource, which collaborates with external partners (i.e. industry, non-profits, and government) and internal partners (i.e. administrative, staff, faculty and students) to offer collaborative opportunities as XYZ U outreaches beyond the classroom. One objective of the Entrepreneur Center is to offer information technology based solution to external and internal partners to maximize productivity while students gain value added field experience. In August 2010, the Entrepreneur Center extended an offer to the CIS program to review, design and develop a decision support system (DSS) to track and monitor the trends for student internships for the Internship Center. The project opportunity fit in nicely with the course, CIS325 Introduction to Information Systems, where the students would build an improved reporting solution for the Internship Center.

\section{Project Background}

The Internship Center Director and support personnel were looking for a better and more efficient method to track internship growth throughout the university to assist in problem solving and decision making. They were looking for a decision support system to track the number of students by internship type (i.e. practicum, student teaching, clinical) across data mining techniques such as program major, department, college, term and semester. By improving tracking and trend reporting methods, Internship Center personnel would have better insight into the recommending changes and improvements to the internship registration process for students at the program level.

With spreadsheets available from the summer 2004 through fall 2010, data was analyzed to evaluate the number of students who participated in internships across various dimensions. The intent was to develop drill down, data mining reporting solutions at the college, department or program level aggregated by year and semester. 
One primary objective of the project was to remove the unstructured workflow where Internship Center personnel used Excel spreadsheets and paper documents to track the number of students registered in a course, by semester and term, for each program and department. The intent for the project, which evolved into the final project for students in CIS325 Introduction to Decision Support Systems, was for students to define and build a centralized, cleansed data warehouse data source and provide standard reporting solutions via queries and customized reports through the use of Microsoft Excel Pivot tables.

Outcomes gained from the project provided the students experience in building computer information systems, where they received

- exposure to the "social networking" side of analysis and design by understanding the interpersonal skills needed for interviewing, and

- experience in building technically based computer systems that are used in problem solving and decision making in the workplace.

Students participated in all levels of the systems development lifecycle (planning, analysis, design, development, and implementation) by working closely with faculty, Internship Center users and Entrepreneur Center staff personnel. As noted by researchers in the information systems area (Schwalbe 2007), the high failure rate for information systems design projects is due to the lack of understanding of the system from the end users' perspectives because the designer tends to view the project from a technical perspective. This project helped to alleviate that problem while exposing students to applied, practical field experiences.

\section{Process Workflow and Project Solution}

For this project, students analyzed over $21 \mathrm{MS}$ Excel spreadsheets to gain functional intelligence on the existing data and to design an improved reporting solution. .

Once an understanding of the data requirements were captured, the students concentrated on cleansing the data with consistent field value descriptions and used de-normalized database design techniques to position the data for reporting purposes.

Table 1 captures at a summary level the accomplishments of the students through the systems development lifecycle. The table notes the work breakdown structure of activities, the timeline in the semester that the work was accomplished, and the overall outcomes and deliverables provided by the students. In essence, it captures the project management overview and final synopsis of the project.

In November 2010, the students provided training to the Internship Center personnel where the decision support system was enthusiastically accepted with plans to move the solution into a dayto-day operational, production mode. Feedback from the students confirmed that the project had remarkable value in gaining actual field experience in developing decision support systems while feedback from the Internship Center personnel has been extremely positive with the pilot being promoted as a "standard process" to consider for future Entrepreneur Center projects. The opportunity to create a user accepted decision support solution, while balancing analysis, critical thinking and unstructured problems in the user community, was a major success for the students in this service learning endeavor. 


\begin{tabular}{|c|c|c|c|}
\hline \multicolumn{4}{|c|}{ Table 1: Systems Development Life Cycle } \\
\hline Phases & Work Breakdown & Timeline & Outcomes \\
\hline $\begin{array}{l}\text { Phase I: Investiga- } \\
\text { tion and Analysis }\end{array}$ & $\begin{array}{l}\text { Reviewed the existing process to } \\
\text { maintain multiple Excel spread- } \\
\text { sheets and defined the reporting } \\
\text { problems associated with the cur- } \\
\text { rent process. }\end{array}$ & $\begin{array}{l}\text { September } \\
2010\end{array}$ & $\begin{array}{l}\text { Project Proposal Document by } \\
\text { students: Confirmed project } \\
\text { objectives and scope. }\end{array}$ \\
\hline $\begin{array}{l}\text { Phase II: User re- } \\
\text { quirements, techni- } \\
\text { cal specs }\end{array}$ & $\begin{array}{l}\text { Defined the reporting needs of the } \\
\text { researchers and archivists and the } \\
\text { technology needed for the new } \\
\text { system. }\end{array}$ & October 2010 & $\begin{array}{l}\text { User needs, technical spec } \\
\text { docs by students: received } \\
\text { archivists' and faculty ap- } \\
\text { proval. }\end{array}$ \\
\hline $\begin{array}{l}\text { Phase III: Data- } \\
\text { base and Applica- } \\
\text { tion development }\end{array}$ & $\begin{array}{l}\text { Built and constructed the central- } \\
\text { ized data warehouse with } \\
\text { "cleansed" data. Developed the } \\
\text { application solution with MS Excel } \\
\text { and Pivot Table reporting. }\end{array}$ & $\begin{array}{l}\text { November } \\
2010\end{array}$ & $\begin{array}{l}\text { Students began migration of } \\
\text { individual databases into cen- } \\
\text { tralized solution. Students de- } \\
\text { veloped summary and detailed } \\
\text { reports. Review and approval } \\
\text { on completed work. }\end{array}$ \\
\hline $\begin{array}{l}\text { Phase IV: User } \\
\text { testing and accep- } \\
\text { tance }\end{array}$ & $\begin{array}{l}\text { Created a system test plan for In- } \\
\text { ternship Center personnel to review } \\
\text { the reports and test for adequacy. } \\
\text { This phase is an iterative process } \\
\text { where versions of the system were } \\
\text { reviewed to ensure that the solution } \\
\text { met the project scope and their } \\
\text { business needs. }\end{array}$ & $\begin{array}{l}\text { November } \\
2010- \\
\text { December } \\
2010\end{array}$ & $\begin{array}{l}\text { Students installed centralized } \\
\text { spreadsheet and Pivot Table } \\
\text { reporting solution where In- } \\
\text { ternship personnel reviewed } \\
\text { the system with approval or } \\
\text { disapprove on adequacy of } \\
\text { system. Change requests were } \\
\text { captured by the students as } \\
\text { enhancements. Initial results } \\
\text { from users - very promising. }\end{array}$ \\
\hline $\begin{array}{l}\text { Phase V: Imple- } \\
\text { mentation, Docu- } \\
\text { mentation }\end{array}$ & $\begin{array}{l}\text { Moved the solution into produc- } \\
\text { tion, for use in day-to-day opera- } \\
\text { tions by the users. }\end{array}$ & $\begin{array}{l}\text { Planned for } \\
\text { December } \\
2010 \text { through } \\
\text { January } 2011\end{array}$ & $\begin{array}{l}\text { Students: User manual and } \\
\text { system procedures were cre- } \\
\text { ated. Plans to implement sys- } \\
\text { tem at the Internship Center } \\
\text { planned for 1Q2011. }\end{array}$ \\
\hline
\end{tabular}

\section{Summary and Future Research}

While service learning has its origins through volunteer and community service initiatives, recently it has been integrated into academic curricula beyond the humanities. In particular, business and information systems curricula because of their applied and skill based subject matter, have embraced the integration of student learning in the classroom with practical application in the community. In the attempt to establish standards for academic quality and a basis for certifying quality programs, professional accreditations have become a focus for institutions of higher education worldwide.

With strict and rigorous standard established by these professional accreditations - it is not possible but advantageous to integrate service learning into the curriculum.

This paper used one case study to demonstrate how a required and standards driven course in an accredited ABET-CAC IS program was integrated into a service learning project. Not only were the IS course objectives met, but were met with greater effectiveness through a real application provided by the service learning experience. The example provided included the design, devel- 
Integrating Service Learning and Civic Engagement Opportunities

opment and implementation of an application that had specific requirements, testing issues, deadlines, and user considerations.

This case further can be used as an example as how requirements for European accreditations such as FIBAA can be satisfied. Involvement with the local community and economy resulted in an ongoing partnership that provides for community development that most likely would not have happened had it not been for the service learning environment. Secondly, the rigorous accreditation standards and periodic audits and certification assure quality service and work and supervision for the community project. Additionally, service learning projects are not necessarily limited to the local community. Projects can be designed with an international frame as a context - such as nursing students going to Nicaragua to staff a backcountry clinic that would not otherwise have access to medical personnel. Finally, future research is underway to assess the effectiveness of courses done in service learning mode compared to the traditional classroom mode. Likewise economic assessment is being done to measure the value added to the community as a result of the service learning project.

\section{References}

ABET. (2010). Programs accredited by country. Retrieved 19 November 2010 from http://www.abet.org/AccredProgramSearch/AccreditationSearch.aspx

Abregana, B. (2006). Service learning as a new pedagogy in higher education. Surabaya: National Seminar on Service Learning.

Bandura, A. (1977). Social learning theory. New York: General Learning Press.

Battistoni, R. M. (2002). Civic engagement across the curriculum: A resource book for service-learning faculty in all disciplines. RI: Campus Compact.

BiblioMondo. (2008). A new generation of library technologies. BiblioMondo - ISACS Software. Retrieved 7 Dec. 2008 http://www.bibliomondo.com

Billig, S., \& Furco, A. (2002). Service-learning through a multidisciplinary lens: Advances in servicelearning research. Greenwich, CT: Information Age.

Brown, A. L., Metz, K. E., \& Campione, J. C. (1996). Social interaction and individual understanding in a community of learners. The influence of Piaget and Vygotsky. In A. Tryphon \& J. Voneche (Eds.), Piaget-Vygotsky: The social genius of thought (pp. 145-170). New York: Psychology Press.

Brown, A. L., \& Palinscar, A. M. (1989). Guided, cooperative learning and individual knowledge acquisition. In L. B. Resnick (Ed.), Cognition and instruction: Issues and agendas (pp. 393-451). Hillsdale, NJ: Lawrence Erlbaum.

Carver, R.L. (1997). TheoretiXYZ Underpinnings of service learning. Theory into Practice, 36(3), 143149.

Dewey, J. (1916). Democracy and education: An introduction to the philosophy of education. New York: Macmillan.

FIBAA. (2010). Foundation for international business administration accreditation. Retrieved 19 November 2010, http://www.fibaa.de/programmakkreditierung.htm

Giles, D. E., Jr., \& Eyler, J. (1994). Theoretical roots of service learning in John Dewey: Toward a theory of service learning. Michigan Journal of Community Service Learning, (Fall), 77-85.

Gilliland-Swetland, A. J., Chandler, R. L., \& White, L. (2003). MOAC II user evaluation: Making museum content useful. Proceedings of the $66^{\text {th }}$ Annual Meeting of the American Society for Information \& Technology-Humanizing Information Technology, Long Beach, California, October 20 - 23, 2003 (Medford, NJ.: Information Today, 2003). 
Gray, M. J., Ondaatje, E. H., \& Zakaras, L. (1999). Combining service and learning in higher education. Summary report. Santa Monica, CA: Rand.

Howard, J. P. F. (1998). Academic service learning: A counternormative pedagogy. In R. A. Rhoads \& J. P. F.Howard (Eds.), Academic service learning: A pedagogy of action and reflection (pp. 21-29). San Francisco: Jossey-Bass Publishers.

Jonassen, D., \& Henning, P. (1999). Mental models: Knowledge in the head and knowledge in the world. Educational Technology, 39(3), 37-42.

Lesh, R. (2002). Research design in mathematics education: Focusing on design experiments. In L. English (Ed.), International handbook of research design in mathematics education (pp. 27-51). Mahwah, NJ: Lawrence Erlbaum.

Manchester, H., \& Baiocchi, L. (2001). Reflecting on Jonathan Kozol's challenge: Who really benefits from service learning? Currents: The Newsletter of Youth Service California, IX(3). Retrieved from http://www.energizeinc.com/art/vvser.html

Mattson, K. (1998). Can service-learning transform the modern university? A lesson from history. Michigan Journal of Community Service-Learning, 5(Fall), 108-113.

McPherson, K. (1996) Service-learning: Getting to the heart of school renewal. Vancouver, WA: School Improvement Project.

Mendel-Reyes, M. (1998). A pedagogy for citizenship: Service learning and democratic education. In R. A. Rhoads \& J. P. F. Howard (Eds.), Academic service learning: A pedagogy of action and reflection (pp. 31-38). San Francisco: Jossey-Bass.

Roehlkepartain, E.C. (2007). Benefits of community-based service-learning. Scotts Valley, CA: Learn and Serve America's National Service-Learning Clearinghouse. Retrieved from http://servicelearning.org/instant_info/fact_sheets/cb_facts/benefits_cbosl/index.php

Schwalbe, K. (2007). Information technology Project management (5th ed.). Boston, MA: Course Techno$\log$.

Stanton, T. K., Giles, D. E., \& Cruz, N. I. (1999). Service-learning: A movement's pioneers reflect on its origins, practice, and future. San Francisco: Jossey Bass.

Sweeney, A. E., \& Paradis, J. A. (2004). Developing a laboratory model for the professional preparation of future science teachers: A situated cognition perspective. Research in Science Education, 34, 195-219.

Vygotsky, L. S. (1978). Mind in society. Cambridge, MA: Harvard Press.

Weigert, K. M. (1998). Academic service learning: Its meaning and relevance. In R. A. Rhoads \& J. P. F. Howard (Eds.), Academic service learning: A pedagogy of action and reflection (pp. 3-10). San Francisco: Jossey-Bass.

Wenger E., McDermott, R., \& Snyder, W. M. (2002). A guide to managing knowledge: Cultivating communities of practice. Cambridge, MA: Harvard University Press. 


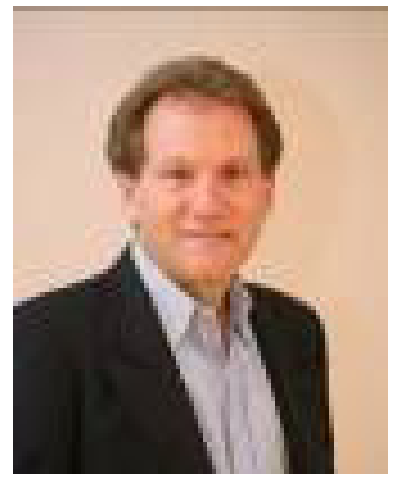

\section{Biographies}

Gary J. DeLorenzo, D. Sc. Associate Professor in Computer Information Systems and Director, Leadership Studies at California University of Pennsylvania, has more than 30 years practical business experience in industry with more than 20 years experience as a faculty professor in the areas of business and information systems. He holds a bachelor degree in business from Indiana University of Pennsylvania, a Masters Business Administration degree from Duquesne University, and a Doctor of Science from Robert Morris University.

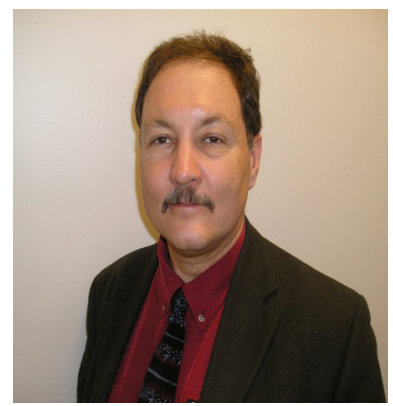

Frederick G. Kohun, Ph.D., Associate Dean and Professor in the School of Communications and Information Systems at Robert Morris University in Pittsburgh, has more than 30 years experience as a professor and administrator in the information systems field. He holds a bachelor degree in economics from Georgetown University, graduate degrees in economics and information science, from the University of Pittsburgh, and a Ph.D. in applied history in technology from Carnegie Mellon University. He had a leadership role in the design and implementation of eight technology based academic programs at the undergraduate and graduate level including a doctoral program at Robert Morris.

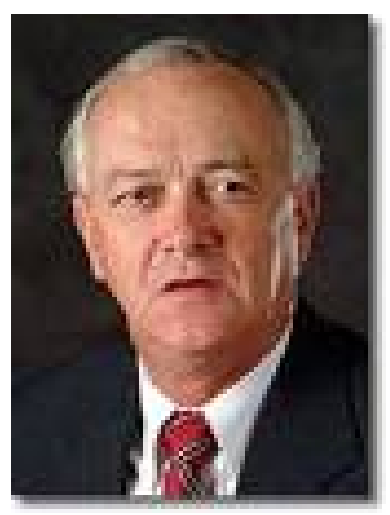

G. Daryl Nord is Professor of Management at Oklahoma State University. He is an active researcher and has published numerous articles and professional proceedings in areas including artificial intelligence/expert systems, systems analysis and design, the Internet, electronic commerce and others. He has served on national and international committees for professional organizations including Decision Sciences Institute, the Natural and Artificial Intelligence Systems Organization. Daryl serves as Managing Director to the IACIS Executive Board and Executive Editor of The Journal of Computer Information Systems.

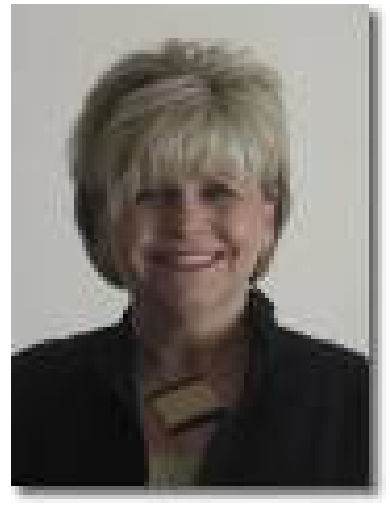

Jeretta Horn Nord is Professor of Management Information Systems at Oklahoma State University. She has recently served as Visiting Scholar at the University of California at Los Angeles and as a Visiting Professor at the University of Southern Queensland in Toowoomba, Australia; she has also been named Computer Educator of the Year by IACIS. She has authored numerous articles, proceedings and conference papers in the areas of e-business and corporate knowledge requirements. Jeretta serves as Director of Publications to the IACIS Executive Board and Executive Editor of The Journal of Computer Information Systems. 